\title{
Student and Teacher Perceptions of Motivational Strategies in the Foreign Language Classroom
}

Ashley Ruesch

Brigham Young University - Provo

Follow this and additional works at: https://scholarsarchive.byu.edu/etd

Part of the Other Languages, Societies, and Cultures Commons

\section{BYU ScholarsArchive Citation}

Ruesch, Ashley, "Student and Teacher Perceptions of Motivational Strategies in the Foreign Language Classroom" (2009). Theses and Dissertations. 1853.

https://scholarsarchive.byu.edu/etd/1853

This Thesis is brought to you for free and open access by BYU ScholarsArchive. It has been accepted for inclusion in Theses and Dissertations by an authorized administrator of BYU ScholarsArchive. For more information, please contact scholarsarchive@byu.edu, ellen_amatangelo@byu.edu. 
STUDENT AND TEACHER PERCEPTIONS OF MOTIVATIONAL STRATEGIES IN THE FOREIGN LANGUAGE CLASSROOM

by

Ashley Ruesch

A thesis submitted to the faculty of

Brigham Young University

in partial fulfillment of the requirements for the degree of

Masters of Arts

Center for Language Studies

Brigham Young University

August 2009 
Copyright (C) 2009 Ashley Ruesch

All Rights Reserved 


\section{BRIGHAM YOUNG UNTVERSITY}

\section{GRADUATI COMMIT"TII APPROVAL.}

of a thesis submilted by

Ashley Ruesch

This thecis has becn read by cach memher ol the following graduate committee and by majority vote has been found to be satisfactery.

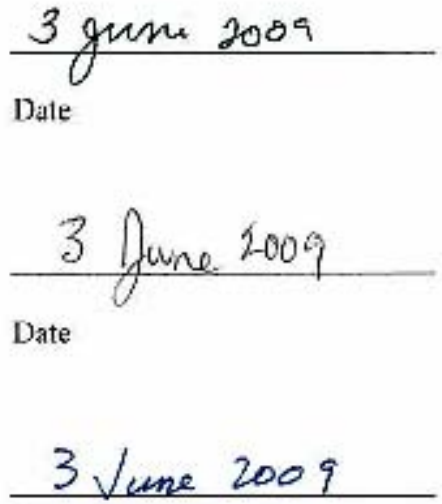

Date gempin Bown

Dr. Jennifer Bown

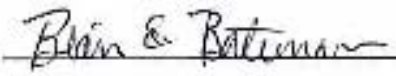

Dr. Rlair Baterran

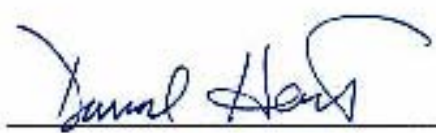

Dr. David Hart 


\section{BRIGHAM YOUNG UNIVERSITY}

As chair of the candidate's graduate committee, I have read the thesis of Ashley Ruesch in its final form and have found that (1) its format, citations, and bibliographical style are consistent and acceptable and fulfill university and department style requirements; (2) its illustrative materials including figures, tables, and charts are in place; and (3) the final manuscript is satisfactory to the graduate committee and is ready for submission to the university library.

Date

Accepted for the Department
Jennifer Bown

Chair, Graduate Committee
Michael Bush

Graduate Coordinator

Accepted for the College

Joseph Parry

Associate Dean

College of Humanities 


\begin{abstract}
STUDENT AND TEACHER PERCEPTIONS OF MOTIVATIONAL STRATEGIES IN THE FOREIGN LANGAUGE CLASSROOM
\end{abstract}

\author{
Ashley Ruesch \\ Center for Language Studies \\ Master of Arts
}

\begin{abstract}
Motivational research has recently shifted focus to include what role teachers, and the motivational strategies they use, play in the language learning classroom (Cheng \& Dörnyei, 2007; Dörnyei \& Csizer, 1998). Motivational research has traditionally gathered data from either teachers or students. However, researchers have recently been calling for a shift in focus from this individualistic perspective to evaluating motivation more holistically (Dörnyei, 2000; Oxford, 2003; Ushioda, 2006). Nevertheless, few studies have included the opinions of both the students and teachers. This study has elicited the opinions of both students and teachers to find out which teaching practices both groups believe foster motivation in the foreign language classroom. The results indicate that students and teachers alike find teaching practices related to Teacher, Rapport, and Climate as the top three most motivational conceptual domains.
\end{abstract}


Furthermore, only 3 conceptual domains, out of 17, were statistically different between groups: Task, Effort, and Comparison. 


\section{ACKNOWLEDGMENTS}

I want to thank a few professors for teaching me and helping me along the way. First and

foremost, I would like to thank Dr. Jennifer Bown, my chair, for dedicating hours and hours to helping me develop my research question and methodology and for reading and editing multiple drafts. Dr. Bown is my hero. I would also like to thank Dr. Wendy Baker and Dr. Dee Gardner for helping me with statistics. Thanks to them, my genius little brothers can no long make fun of me for being the lost cause of the mostly mathbrained family. I would also like to thank Dr. Blair Bateman, Dr. Alan Manning and Dr. David Hart for offering many helpful suggestions and insights. Thank you to Laura Bradford and Jordan Calder for last minute formatting help. Thank you to Havilah Howard for interesting input. Thank you to Jeni Appel for listening to my non-stop thesis ramblings and not making me ban the word "motivation” from our conversations. Thank you also to my family and friends for supporting and encouraging me. 


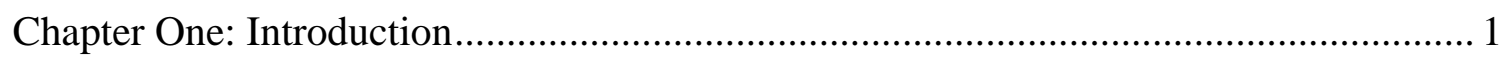

Goal of Study and Research Question ................................................................... 3

Chapter Two: Literature Review................................................................................ 4

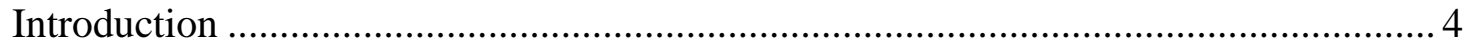

The Definition and Significance of Motivation............................................................ 4

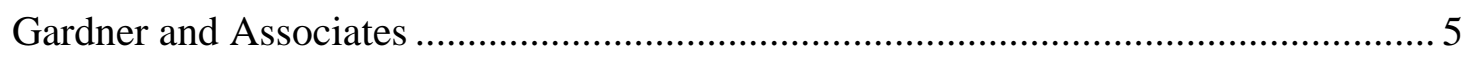

Expanding the View ………………….................................................................. 7

The Dynamic Nature of Motivation ........................................................................... 8

Motivational Strategies and the Teacher's Role..................................................... 9

Dörnyei and Csizer's Commandments for Motivating Language Learners.................. 10

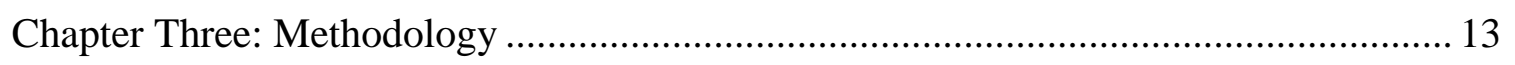

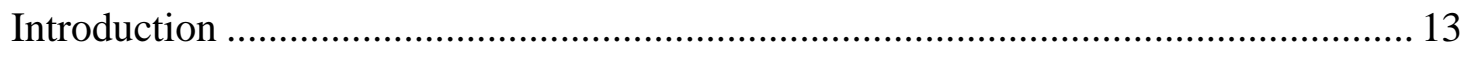

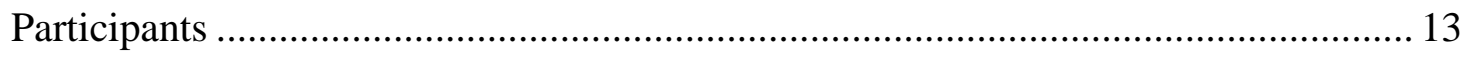

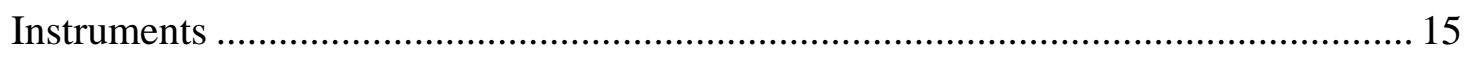

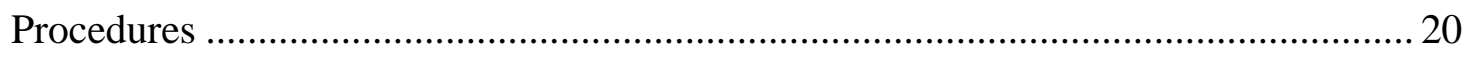

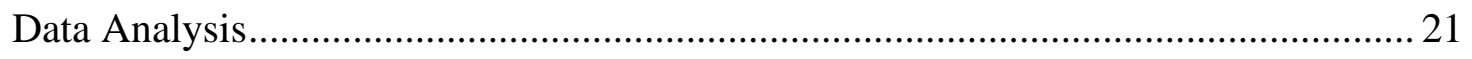

Chapter Four: Results............................................................................................. 23

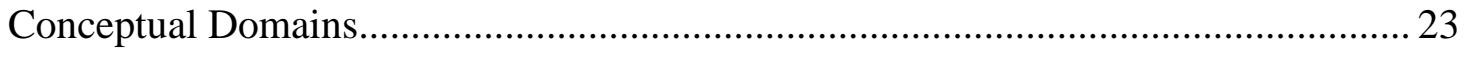

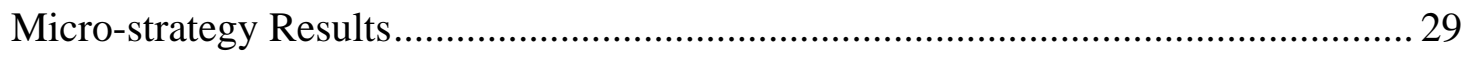

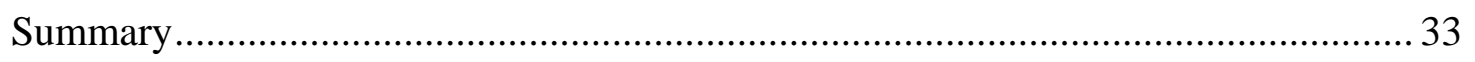

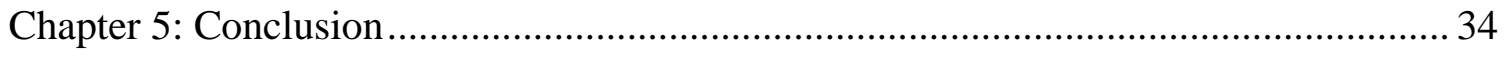

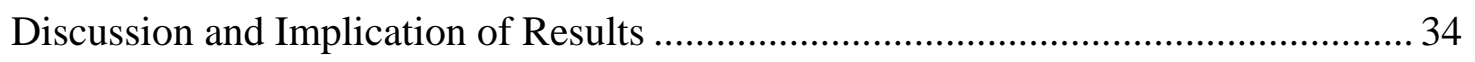

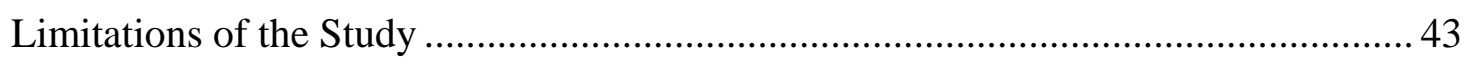

Suggestions for Future Research ................................................................................ 44

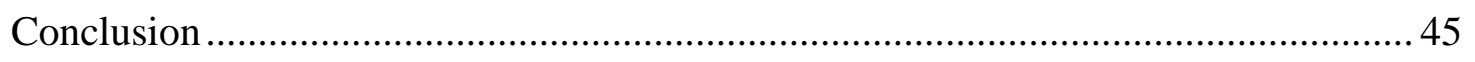

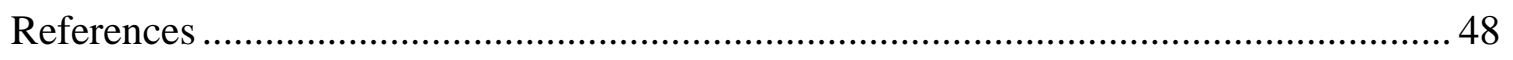




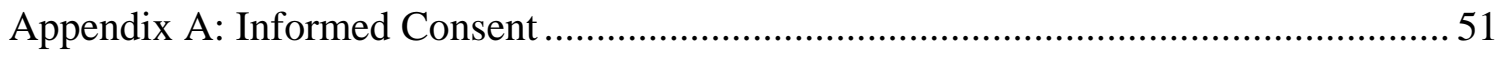

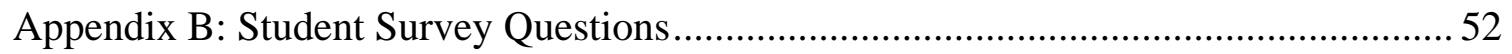

Appendix C: Teacher Survey Questions .............................................................. 56

Appendix D: Student Survey Micro-Stategy Results Rank-ordered.............................. 60

Appendix E: Teacher Survey Micro-Strategy Results Rank-ordered ............................ 62 


\section{List of Tables}

Table 1: Foreign language class breakdown of student participants............................14

Table 2: Foreign language breakdown of teacher participants..................................15

Table 3: Conceptual domains and micro-strategies ..............................................18

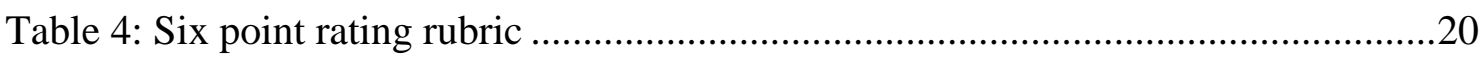

Table 5: Conceptual Domain Explanation ..........................................................24

Table 6: Student and teacher conceptual domain rankings .......................................25

Table 7: Most motivational conceptual domains according to students and teachers.....28

Table 8: $t$ tests on averaged questions results..................................................29

Table 9: Micro-strategy student and teacher results...............................................31

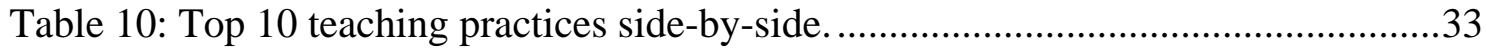

Table 11: Most motivational conceptual domains according to students and teachers...35

Table 12: Most motivational teaching practices to least motivational teaching practice 37

Table 13: Ten Commandments for motivating language learners ..............................39

Table 14: Comparison of Csizer and Dörnyei and Ruesch ......................................40

Table 15: Conceptual domains that are statistically different between groups ...............41 


\section{Chapter One}

Introduction

An ever-present factor in foreign language classrooms for teachers is motivation. Teachers wonder why students to choose to enroll in a particular foreign language class, and they wonder what intrinsically motivates their students to succeed. Recently, teachers and researchers have been concerned with what role the teacher plays in increasing students’ motivation to learn. Particularly, how can teachers adapt their teaching practices in a way that will foster students' intrinsic motivation to succeed at learning a foreign language?

Previous research in the field of motivation indicates that teachers really can make a difference in fostering students’ intrinsic motivation (Cheng \& Dörnyei, 2007; Dörnyei, 2001; Dörnyei \& Csizer, 1998; Ushioda, 2006). A recent student of French at Utah Valley University told the researcher:

[My teacher] really motivated me in my French class. I had him for two quarters and he was better than the other three foreign language teachers I had, because he was awesome! He was so animated. He NEVER said ANYTHING in English. It was awesome! Ordinarily, this would be terribly frightening, but he was a mime artist...with speaking. He would act out everything he said. He always used his hands and demonstrated what he was saying. Often times, people would confuse the word for horse with the word for hair. He would act out the difference saying "not horse" while galloping, then would say "hair" (in French of course) while pretending to brush his bald head. Ha. He was very lively and energetic. By acting everything out, I was able to survive a "no English" French class. 
Additionally, he had us use reading strategies to come to understand different things we read. He would have us act out in groups short stories and poems. We would then sit in groups, decode the poem, talk about it, and act it out. It was great! For the first time after a year of studying French, I started to progress significantly and to feel like I could get it (H. Howard, personal communication, November 12, 2008).

In a highly influential study of motivation, Crookes and Schmidt (1991) called on researchers to focus not only on finding out what motivates students, but to focus on what concepts of motivation teachers believe are critical for successful language learning. Furthermore, Dörnyei says "the most pressing question related to motivation is not what motivation is but rather how it can be increased” (Dörnyei, 2001, p. 51). Although researchers have answered this call by concentrating on how to motivate language learners, much of the previous research has elicited data from either teachers or from students. Teachers and researchers alike have much to gain from understanding both students' and teachers' opinions and their relationship in the foreign language classroom. Ushioda (2006) and Dörnyei (2000) appeal for a more "holistic” approach in motivational research. They suggest that to gain a better understanding of motivation in the language learning classroom, researchers need to examine the relationship between the students and the teacher.

Dörnyei and Csizer (1998) proposed a list of the 10 most motivating conceptual domains, which they called the 10 Commandments that teachers can use in their classroom to increase motivation. Dörnyei and Csizer (1998) sent a survey to 200 teachers asking which strategies they felt were most important to motivating foreign 
language learners, and which strategies were most frequently used in the classroom. This study offered great insight into what motivational strategies teachers found important, but ultimately, it wrote students out of the equation by not eliciting students' opinions as well. If we are interested in finding out how teachers can foster students' intrinsic motivation, we need to do what Oxford and Shearin (1994) suggest and ask them.

\section{Goal of Study and Research Question}

The main goal of this study is to help teachers understand what teaching practices they can use in the classroom that will increase students' intrinsic motivation to learn.

This study will answer Ushioda’s call (2006) to take a more holistic approach by focusing on both teachers and students as integral parts to the whole equation. This study will use most of the same motivational strategies Dörnyei and Csizer (1998) use, but will elicit data from both teachers and students from the same language learning environment, namely students enrolled in foreign language classes at Brigham Young University and their teachers. By gaining an understanding of which teaching practices teachers feel are motivational, and which teaching practices students find motivational, we can find out which teaching practices teachers can use to connect more to students in the foreign language classroom. This study will attempt to gain a better understanding of motivation by addressing the following questions:

1. What motivational strategies used in the classroom do teachers think are most effective?

2. What motivational strategies used in the classroom do students find most effective?

3. How do the perceptions of students and teachers compare? 


\section{Chapter Two}

Literature Review

\section{Introduction}

What drives students in a foreign language learning situation to want to learn a particular foreign language? What forces work to trigger and sustain interest in a foreign language learner? What motivates foreign language learners to go to class every day, immerse themselves in the language and work hard to achieve in language learning? What motivates students to achieve in the foreign language learning classroom is a question in which applied linguists have long been interested. Researchers have investigated what motivation is, what role motivation plays in second and foreign language learning, and more recently, how teachers can stimulate and sustain motivation in foreign language learners.

\section{The Definition and Significance of Motivation}

Many researchers have examined and defined motivation in second and foreign language learning. A broad definition offered by Gardner (1985) is "the extent to which the individual works or strives to learn the language because of a desire to do so and the satisfaction experienced in this activity” (p. 10). Scholars have elaborated on Gardner’s definition (Crookes \& Schmidt, 1991; Dörnyei, 1990; Ely, 1986; Oxford \& Shearin, 1994; Tremblay \& Gardner, 1995) and how it affects language learning. However, as Oxford and Shearin (1994) contend, understanding motivation is hindered by a lack of consensus as to the definition of motivation.

Although opinions differ as to the definition of L2 learning motivation, there is a general agreement on both the important role that motivation plays in the success of 
language learning and the significance of continued research. Dörnyei and Csizer (1998),

for instance, assert that "L2 motivation is one of the most important factors that determine the rate and success of L2 attainment... without sufficient motivation, even individuals with the most remarkable abilities cannot accomplish long-term goals” (p. 203).

This chapter will provide an overview of the history of motivation research beginning with the pioneering theories of Gardner and associates, moving to an explanation of how the definition of motivation expanded and changed, and finally explaining the necessity of shifting the focus of research to how to increase students' motivation in the foreign language classroom. This chapter will conclude with an explanation of the research question.

\section{Gardner and Associates}

Robert C. Gardner, Wallace Lambert, Richard Clement, and their associates were among the first linguists to shed light on the importance of motivation in language learning. Gardner, researching mostly in a second language environment in Canada, took a social-psychological approach to explaining motivation. He claimed that individuals strive to learn a second or foreign language for two distinct reasons. The first reason he

termed the integrative orientation and the second explanation he termed the instrumental orientation. Learners may be positively drawn to the culture of the target language and may desire to integrate into that culture. This goal is termed integrative. On the other hand, individuals may wish to study a language in order to achieve an end, such as getting a job, obtaining a salary increase, or having a competitive edge over another, professionally. Such goals arise from an instrumental orientation. 
Gardner's Social-Psychological Model also asserts that in order for motivation to exist, effort must be expended, the student must want to learn the language and the learner must experience satisfaction with language learning (Tremblay \& Gardner, 1995). Gardner proposed a method of assessing both motivation and attitudes toward language learning called the Attitude/Motivation Test Battery (AMTB). This measure includes five categories: integrativeness, attitudes toward the learning situation, motivation, language anxiety, and other attributes (Gardner, Masgoret, Tennant, \& Mihic, 2004). Gardner's theory had a tremendous impact on motivation research for decades. In fact, Gardner's distinction between integrative and instrumental orientations to language learning has, as Green (1999) stated, "virtually become a linguistic law” (p. 226).

However, Gardner's dichotomous theory is being challenged. Scholars argue that Gardner's theory applies in only one learning situation, namely second language learners in Canada (Green, 1999), ignoring the foreign language environment (Dörnyei; 1994; Ely, 1986; Green, 1999) ${ }^{1}$. Furthermore, scholars agree that there are numerous other factors that might motivate a student to learn, and that these motivations may change over time (Oxford \& Shearin, 1994; Shoaib \& Dörnyei, 2005). Gardner's theory focuses on individual differences in motivation, rather than on how teachers can better teach languages or how teachers can motivate students to learn (Crookes \& Schmidt, 1991; Dörnyei, 2001a). Nevertheless, Gardner and his associates were the first to draw

\footnotetext{
${ }^{1}$ Second language learning is when learners are immersed in the target language and culture of the language they are learning. Foreign language learning is when learners are studying the target language in a country where the target language is not spoken by the general population.
} 
attention to motivation, and their research set the stage for other scholars to expand the view of L2 motivation.

Expanding the View

Ely (1986) was among the first to examine motivation in the context of the foreign language classroom. His findings confirmed that integrative and instrumental motives do indeed play a role in foreign language learning. However, Ely also found that learners in a foreign language environment were also motivated simply by the need to fulfill the language requirement at their university, a fact Gardner and Lambert had not considered when researching in a second language environment.

Though Ely found that instrumental and integrative orientations do play a role in foreign language learning, Dörnyei (1990) contends that these orientations are manifested differently in the foreign language setting. According to Gardner's original formulation, motivation reflects the attitude the language learner holds toward the target language community and culture (Crookes \& Schmidt, 1991). Yet in foreign language contexts, learners have limited access to the target community. Thus, integrative motivation for foreign language learners represents a general attitude toward foreign languages and cultures and the value attached to learning about a new culture (Dörnyei, 1990; Oxford \& Shearin, 1994). Norton (2001) contends that foreign language learners may also identify with an "imagined community," a community that learners anticipate joining in the future.

More recently, Dörnyei and his colleagues (Csizer \& Dörnyei, 2005) have extended the idea of integrativeness to indicate not only an affinity towards the L2 community, but a "basic identification process within the individual's self-concept” (p. 
29). According to Csizer and Dörnyei’s (2005) L2 Motivational Self System, learners construct visions of themselves in the future; in particular they create an ideal L2 selfone who can interact with a community of L2 speakers in the future. The authors suggest that "motivation...can be seen as the desire to reduce the perceived discrepancies between the learner's actual and possible (ideal) self” (p. 29). The learner's ideal self is described as how learners imagine themselves as future speakers of the target language. The ideal self also includes the language achievement goals learners have and the process they will go through to accomplish these goals. The actual self is how the speaker currently and actually performs in the target language. The L2 ideal self is seen as a motivating factor to help move the actual self forward in the language learning process. Thinking of integrativeness in terms of achieving an ideal L2 self broadens the idea of instrumentality as well. For example, the L2 ideal self could include speaking the L2 well for professional reasons.

The Dynamic Nature of Motivation

Recently, scholars have expanded the traditional definition of language learning motivation to fit into different and involved realms of language learning. Researchers have theorized and explained many different reasons for language learners' motivation. Motivation to achieve is tied to individuals' personal, scholastic, and professional goals, as well as to their self-concept and identities, both imagined and real. Motivation is also linked to interaction within the target community and a potential desire to integrate into either the target community, or the global community of language learners (Ryan, 2006).

Researchers have also asserted that motivations may not only be intricate, but they also might change over time. Green (1999) asserts that "few research findings take 
into account the dynamic potential of motivational drives to change with the maturation, experience and developing world view of the individual learner” (p. 267). Dörnyei (2001) terms this idea the “temporal dimension of motivation” (p. 45), and agrees that student motivation undergoes constant change instead of staying the same. The original motives for language learning may change as learners gain more experience with language learning. Oxford and Shearin (1994) illustrate this idea with an example of one woman’s changing motivational drives as she learned Russian. Her initial motive for learning was to communicate with her boyfriend using the Cyrillic alphabet as a secret code. Later she was motivated by the idea of learning a valuable and prestigious language, and by possible career options. By the end of the study, the learner saw Russian as a valuable communication tool.

Motivational Strategies and the Teacher's Role

Much of the previous research focused on constructing a theoretical framework for motivation and concentrated on identifying and defining student motivation, rather than on how to motivate students in the classroom, which, as Dörnyei (2001) notes, may be "the most pressing question related to motivation" (p. 51). Oxford and Shearin (1994) explain that teachers, who are often unaware of what motivates their students, will often make assumptions about the learners’ motives. However, as Dörnyei (1990) points out, teachers should not treat language learning "as a homogenous process” (p. 7); rather, they must strive to understand the complex processes involved in motivation "by treating separately the different learner behaviors that result in language attainment...some behaviors are a function of classroom and teacher-specific variables rather than students' original motivation” (p. 7). That is, teachers must understand the role they play in 
motivating students. Instructors should discover what motivates students, employ teaching methods and materials that appeal to learners' initial motivations, and perhaps create new motivation to continue learning the language in a classroom setting and on their own.

Oxford and Shearin (1994) suggest ways teachers can sustain and increase the motivation of foreign language learners. As a first step, teachers can find out why students chose to study the target language that they chose. Furthermore, teachers can aid in creating an attitude of success in language learning by promoting a positive environment, encouraging positive attitudes, and helping individual students set language learning goals (Oxford \& Shearin, 1994). Oxford and Shearin also encourage the idea of extrinsic reward for progress as well as encouraging students to develop their own intrinsic motivation. Extrinsic reward/motivation includes any type of external incentive for achievement such as grades, prizes or money, and intrinsic motivation refers to any motivation that comes from within the individual such as the desire to achieve or accomplish personal goals. Teachers can also increase student motivation "by demonstrating that L2 learning can be an exciting mental challenge, a career enhancer, a vehicle to cultural awareness and friendship, and a key to world peace” (p. 24). Teachers can also introduce the target culture into the class and show that learning the language has real-world communicative value and application.

\section{Dörnyei and Csizer's Commandments for Motivating Language Learners}

Dörnyei and Csizer (1998) offer additional suggestions for motivating language learners. Their study concerns the importance of helping teachers develop techniques for increasing students’ motivation. Dörnyei and Csizer surveyed 200 foreign language 
teachers, asking them to rate the frequency and importance of a set of 51 teaching strategies. The frequency ratings indicates how often the teaching strategy was used in the classroom, and the importance rating indicated how important teachers perceived the teaching strategy was in order to increase student motivation. From this survey, Dörnyei and Csizer compiled a list of the 10 most important teaching practices to include in classroom instruction, or the "Ten Commandments" for motivating language learners. The Ten Commandments include preparing for lessons, creating a positive learning environment, giving clear instructions, developing a good relationship with the students, giving positive feedback, selecting interesting tasks, encouraging creative ideas, making the content personally relevant, helping the students set and achieve realistic goals, and familiarizing learners of the language with the cultural background of the target language.

Dörnyei and Csizer’s 10 commandments for motivating language learners represent an important first step in understanding how teachers can motivate their students. However, their research, and later research (Cheng \& Dörnyei 2007), focused exclusively on the perspectives of teachers and did not take into account the perspectives of learners. Other studies (Price \& Gascoigne, 2006; Roberts, 1992) elicit students’ views on motivation while ignoring perceptions of their instructors. This insistence on treating students and teachers as separate units is particularly troubling in light of a growing recognition that language learning is a socially-mediated process. In fact, Ushioda (2006) asserts that motivation itself is a socially mediated process, that it "is not located solely within the individual but is socially distributed, created within cultural systems of activities involving the mediation of others” (p. 154). In order to provide a 
more accurate picture of L2 motivation, scholars must consider the perceptions of both students and teachers.

The present study will seek to address this gap in the research, by focusing on the perceptions of teachers and students. This study will attempt to gain a better understanding of how teachers can foster students' motivation to learn by asking the following questions:

1. What motivational strategies used in the classroom do teachers think are most effective?

2. What motivational strategies used in the classroom do students find most effective?

3. How do the perceptions of students and teachers compare? 


\section{Chapter Three}

\section{Methodology}

\section{Introduction}

This chapter will provide an overview of this study's research design, the instruments by which data were collected, and the methodology employed in their analysis.

This chapter will begin with a description of the participants involved in the study. Next it will describe the questionnaires used to elicit data from teachers and students. The following section will describe the procedure used. Finally, this chapter will provide a brief description and justification for the data analysis that will be used.

\section{Participants}

Inasmuch as the focus of the present study is to better understand the opinions of students and teachers from the same language learning setting, only students and teachers enrolled in foreign language classes at Brigham Young University or teaching at Brigham Young University were included in the data collection process.

The student participants involved in this study were enrolled in various beginning levels (101, 102, or 201) of the following foreign language classes at Brigham Young University: Arabic, Chinese, Japanese, French, Spanish, Italian, and Russian. Thirty-nine students were enrolled in a 101 level course, 2 students were enrolled in a 102 level course, 57 were enrolled in a 201 level course, and 28 students did not report in which level they were enrolled. Some students were enrolled different language levels simultaneously. Six students were enrolled in more than one foreign language class simultaneously. Out of the 126 participating students, 125 participants reported basic 
demographic information. A total of 45 male students responded and 80 female students responded to the questionnaire. Students ranged in age from 18 to 28 . Below is a breakdown of how many student participants were enrolled in each different foreign language class.

Table 1.

Foreign Language Class Breakdown of Student Participants

\begin{tabular}{|l|l|}
\hline Foreign Language Class & Number of Students \\
\hline Arabic & $\begin{array}{l}53 \text { (1 student also enrolled in French, 1 } \\
\text { student also enrolled Hebrew, 1 student also } \\
\text { enrolled in Turkish, 1 student also enrolled in } \\
\text { Russian, 3 students also enrolled in Spanish) }\end{array}$ \\
\hline Japanese & 16 (1 student also enrolled in Chinese) \\
\hline Spanish & 18 \\
\hline Italian & 12 \\
\hline French & 10 \\
\hline Russian & 10 \\
\hline Chinese & 6 \\
\hline German & 0 \\
\hline
\end{tabular}

The teacher participants include 30 teachers teaching at various levels (101, 102, 201, 211 and 321) of the following languages: Japanese, French, German, Arabic, Chinese, Italian, Spanish and Russian. Thirteen teachers taught at the 101 course level, six teachers taught at the 102 course level, six teachers taught at the 201 course level, one teacher taught at the 211, three teachers taught at the 321 level, and one teacher did not report this information. Some teachers taught various course levels. Each teacher participant filled out the demographic information section. A total of 21 male teachers responded and 9 female teachers responded. Teachers ranged in age from 22 to 64 . 
Below is a breakdown of each teacher participant and which foreign language class they teach $^{2}$.

Table 2.

Foreign Language Breakdown of Teacher Participants

\begin{tabular}{|l|l|}
\hline $\begin{array}{l}\text { Foreign Language } \\
\text { Class }\end{array}$ & $\begin{array}{l}\text { Number of } \\
\text { Teachers }\end{array}$ \\
\hline Italian & 6 \\
\hline French & 5 \\
\hline Russian & 5 \\
\hline Arabic & 4 \\
\hline Japanese & 4 \\
\hline Spanish & 3 \\
\hline German & 2 \\
\hline Chinese & 1 \\
\hline
\end{tabular}

The teacher survey was sent to 84 teachers who were all asked to fill out the teacher survey online. The teachers were also sent a separate link to an online student survey and asked to forward the link to their students. Out of the 84 teachers to whom the link was sent, 30 completed the teacher survey, and 126 of their students completed the student survey.

Instruments

The primary instruments used in this study consisted of two questionnaires, one administered to teachers of different 101, 102, 201, 211 and 321 foreign languages levels at Brigham Young University and the other administered to students enrolled in their classes. Both questionnaires were administered online using Qualtrics, an online survey software program that provides easy online data collection.

\footnotetext{
${ }^{2}$ The researcher asked each language department at the research site for permission to survey their first and second-year teachers and students. The departments of Germanic and Slavic Languages, Spanish and Portuguese, Asian and Near Eastern Languages, and French and Italian permitted the researcher to email the instructors and provided her with email addresses.
} 
The questionnaires for this study were based on a questionnaire Dörnyei and Csizer (1998) used to rate importance and frequency of different motivational strategies used in Hungarian English classrooms. Dörnyei and Csizer (1998) administered a questionnaire consisting of 51 micro-strategies (teaching practices) and asked 200 teachers to rate on a seven point scale the importance of the strategy used and the frequency of classroom use of each individual strategy (116 of the teachers completed the importance survey, and 84 completed the frequency survey).

Internal validity of the surveys used in this study was established by the researcher and two other raters. Motivational strategies from Dörnyei and Csizer’s study (1998) that did not apply to a college level classroom were eliminated including — "help maintain the set of classroom rules that students accepted," "involve students in creating their own classroom rules," "regularly review the classroom rules with your students," and "encourage the learners to decorate the classroom and make it cosy in any way they can.”

In addition to removing strategies that did not apply to the foreign language learning environment at Brigham Young University, the following strategies that do apply to a college learning environment were included in the questionnaires: "invite experienced students to talk about their positive learning experiences," "teach various learning strategies," “allow students real choice about as many aspects of learning as possible,” and “act as a facilitator” (Dörnyei, 2001a). Additionally, the wording of each strategy was slightly adapted to apply to both students and teachers at Brigham Young University. 
Another important difference between the survey instrument in this study and that of the Dörnyei and Csizer study upon which it is based is the absence of questions related to the frequency with which teachers use particular motivational strategies. For purposes of the present study, the researcher chose to focus only on the extent to which each strategy was perceived as motivational and not on the teachers' actual practices.

The motivational strategies were grouped into similar conceptual domains and also divided into individual micro-strategies. Conceptual domains are larger, moregeneral categories made-up of related micro-strategies. For example, the micro-strategies “creating a pleasant atmosphere in the classroom," and "having activities and fun in class” are individual teaching practices that contribute to the climate of the classroom. Thus, the conceptual domain for this group of related micro-strategies is Climate. Microstrategies are the individual teaching practices that a teacher might use in the classroom to increase students’ motivation such as “creating a pleasant atmosphere in the classroom,” or "having activities and fun in class.” This study consists of 49 individual micro-strategies (teaching practices). The 49 related micro-strategies have been grouped together into 17 larger categories, or conceptual domains. Table 3 presents a list of each conceptual domain and micro-strategy involved in this study, and how they have been grouped. These conceptual domain groupings are taken from previous research (Dörnyei, 2001a; Dörnyei and Csizer, 1998). 
Table 3.

Conceptual Domains and Micro-strategies

\begin{tabular}{|c|c|}
\hline Teacher & $\begin{array}{l}\text { Properly prepare for the lesson. } \\
\text { Show a good example by being committed and motivated to } \\
\text { helping the student succeed. } \\
\text { Behave naturally and genuinely in class. } \\
\text { Be sensitive and accepting. }\end{array}$ \\
\hline Climate & $\begin{array}{l}\text { Create a pleasant atmosphere in class. } \\
\text { Bring in humor, laughter and smile. } \\
\text { Have activities and fun in class. } \\
\text { Have game-like competitions in class. }\end{array}$ \\
\hline Task & $\begin{array}{l}\text { Give clear instructions. } \\
\text { Provide guidance about how to do the task. } \\
\text { Clearly state the purpose and utility of every task. }\end{array}$ \\
\hline Rapport & Develop a good relationship with the students. \\
\hline Self-confidence & $\begin{array}{l}\text { Give positive feedback and appraisal. } \\
\text { Make sure that students experience success regularly. } \\
\text { Encourage students. } \\
\text { Explain that mistakes are a natural part of learning. } \\
\text { Select tasks that do not exceed the learners' competence. } \\
\text { Teach various learning strategies. }\end{array}$ \\
\hline Interest & $\begin{array}{l}\text { Select interesting tasks. } \\
\text { Choose interesting topics. } \\
\text { Offer a variety of materials. } \\
\text { Vary the activities. } \\
\text { Make tasks challenging to involve the students. } \\
\text { Build on the learners' interest rather than tests or grades as } \\
\text { the main energizer for learning. } \\
\text { Raise learners' curiosity by introducing unexpected or exotic } \\
\text { elements. }\end{array}$ \\
\hline Autonomy & $\begin{array}{l}\text { Encourage creative and imaginative ideas. } \\
\text { Encourage questions and other contributions from students. } \\
\text { Share as much responsibility to organize the learning } \\
\text { process with the students as possible. } \\
\text { Allow students real choices about as many aspects of } \\
\text { learning as possible. } \\
\text { Act as a facilitator. }\end{array}$ \\
\hline Personal relevance & $\begin{array}{l}\text { Fill the task with personal content that is relevant to the } \\
\text { students. }\end{array}$ \\
\hline
\end{tabular}




\begin{tabular}{|c|c|}
\hline Goal & $\begin{array}{l}\text { Help the students develop realistic expectations about } \\
\text { learning. } \\
\text { Set up several specific learning goals for the learners. } \\
\text { Increase the group’s goal-orientedness. } \\
\text { Tailor instructions to meet the specific language goals and } \\
\text { needs of the students. } \\
\text { Help students design their individual study plans. }\end{array}$ \\
\hline Culture & $\begin{array}{l}\text { Familiarize the learners with the culture of the language they } \\
\text { are learning. } \\
\text { Use authentic materials (i.e. printed or recorded materials } \\
\text { that were produced for native speakers rather than students). } \\
\text { Invite native speakers to class. } \\
\text { Find penpals or "keypals" (Internet correspondents) for the } \\
\text { students. }\end{array}$ \\
\hline Group & $\begin{array}{l}\text { Include group work in class. } \\
\text { Help students to get to know one another. } \\
\text { Participate as an ordinary member of the group as much as } \\
\text { possible. } \\
\text { Organize extracurricular activities outside of class. }\end{array}$ \\
\hline Effort & $\begin{array}{l}\text { Help students realize it's mainly effort that is needed for } \\
\text { success. }\end{array}$ \\
\hline Language usefulness & Emphasize the usefulness of the language. \\
\hline Reward & Give the learners other rewards besides grades. \\
\hline Finished product & $\begin{array}{l}\text { Allow students to create products that they can display or } \\
\text { perform. }\end{array}$ \\
\hline Comparison & Avoid any comparison of students to one another. \\
\hline Peer-modeling & $\begin{array}{l}\text { Invite experienced students to talk about their positive } \\
\text { learning experiences. }\end{array}$ \\
\hline
\end{tabular}

The student questionnaire presented a list of each of these 49 teaching practices that a teacher might use in the foreign language classroom and asked students to indicate how big a role that particular practice plays in motivating them to learn the language.

Similarly, the teacher questionnaire presented a list of the same 49 teaching practices, and asked instructors to indicate how big a role they believe that particular practice plays in motivating their students to learn.

Inasmuch as the focus of this study is to find out what teaching practices students consider motivational and which teaching practices teachers believe motivate students 
and not to find out how often certain teaching practices are employed, the participants were not asked to rate the frequency of classroom use of each individual strategy.

Each respondent, teacher and student alike, rated each strategy on the following six point scale (0-5).

Table 4.

Six Point Rating Rubric

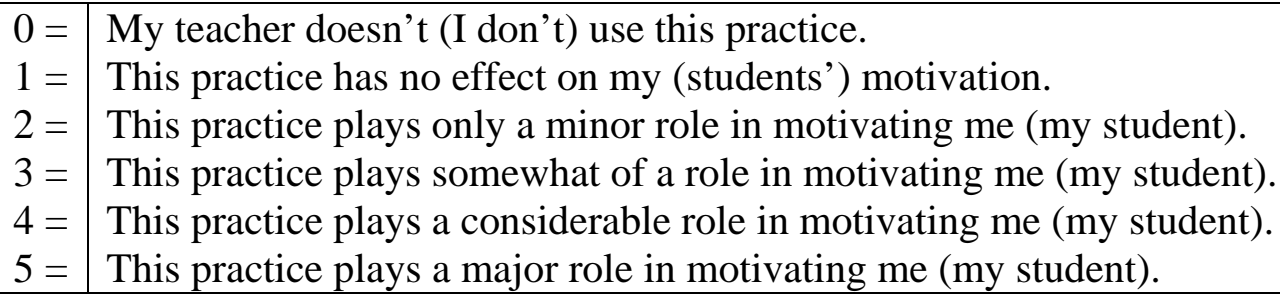

The surveys also contained questions asking for basic demographic information including which language the students were learning, or the teachers were teaching, their age, and gender.

\section{Procedures}

The researcher first obtained Institutional Review board (IRB) approval and then received permission from individual language departments to e-mail teachers the online survey. The instructions on the survey indicated that completing the survey denoted informed consent. The survey link was e-mailed to 84 teachers of different foreign languages at Brigham Young University_-Japanese, French, German, Arabic, Chinese, Italian, Portuguese, Spanish and Russian. Each teacher that participated in the study forwarded the online student survey link to the students in their class. The data were collected by using Qualtrics online survey software. 


\section{Data Analysis}

The purpose of gathering data was to determine which individual teaching practices students find motivational and which individual teaching practices teachers find motivational and to see how they compare. In order to accomplish this, the teaching practices were rank-ordered (highest to lowest) by finding the mean response of each individual teaching practice. This method of analysis yielded two separate rank-ordered lists (one from the teacher responses, and the other from the student responses), and shows which teaching practices (from 1 to 49) teachers find motivational compared to which teaching practices students find motivational.

The data were also analyzed according to each conceptual domain to come up with a rank-ordered list of the most motivational conceptual domains, according to both teachers and students. First, the individual mean of each micro-strategy was calculated. Then, the mean of each individual conceptual domain group was calculated and rankordered. This method of analysis also provides two separate lists, one from the teacher response data, and the other from the student response data.

The data were then analyzed with inferential statistical tests to determine statistical significance of each conceptual domain and to determine statistical significance between student and teacher groups.

Two one-way ANOVAs were performed, one on the student data, and another on the teacher data, to determine if the results of each conceptual domain, as rated by students and then by teachers, were statistically significant. Post-hoc tests were run on both of the one-way ANOVAs to determine exactly where the statistical significance was for the student data and the teacher data. These post-hoc tests provided two rank-ordered 
lists, one of the student data, another of the teacher data. These two lists show which conceptual domains are considered the most motivational and which are considered the least motivational by students and teachers. The post-hoc tests also show which conceptual domains are statistically similar and statistically different from each other.

Additionally, a two-way ANOVA was run to determine if there was a statistical difference between the student and teacher groups, to determine if there was a statistical significance of combined student and teacher rankings by conceptual domain, and if there was any interaction between the two groups and the conceptual domains.

Finally, a series of $t$ tests were run to show which conceptual domains were statistically different between student and teacher groups. The results of each statistical procedure will be presented in Chapter 4 and discussed in Chapter 5. 


\section{Chapter Four}

Results

This chapter will present the results of student perceptions, teacher perceptions, students' and teachers' combined perceptions of each conceptual domain, and then the student and teacher results of each individual micro-strategy ranking.

In order to better understand how students' and teachers’ perceptions of motivational strategies compare, I have divided the data into two categories. The first category consists of individual teaching practices referred to as micro-strategies, and the second category consists of these individual micro-strategies grouped into 17 similar conceptual domains. Inasmuch as the results of the individual micro-strategies were not found to be statistically significant, I will talk about conceptual domains first, and then present the findings of the individual micro-strategies.

\section{Conceptual Domains}

This study includes 17 conceptual domains: teaching, climate, task, selfconfidence, personal relevance, interest, language, usefulness, autonomy, effort, comparison, goal, group, culture, reward, peer-modeling, finished product and rapport (Dörnyei \& Csizer, 1998; Dörnyei, 2001a).

Table 5 presents a brief explanation of each conceptual domain (Dörnyei \& Csizer, 1998; Dörnyei, 2001a). 
Table 5 .

Conceptual Domain Explanation

\begin{tabular}{|c|c|c|}
\hline & $\begin{array}{l}\text { Conceptual } \\
\text { Domain }\end{array}$ & Explanation \\
\hline 1 & Teacher & Set a personal example with your own behavior. \\
\hline 2 & Climate & Create a pleasant, relaxed atmosphere in the classroom. \\
\hline 3 & Task & Present the tasks properly. \\
\hline 4 & Self-confidence & Increase the learners' linguistic self-confidence. \\
\hline 5 & Interest & Make the language classes interesting. \\
\hline 6 & Autonomy & $\begin{array}{l}\text { Promote learner autonomy and allow students choices } \\
\text { about learning. }\end{array}$ \\
\hline 7 & $\begin{array}{l}\text { Personal } \\
\text { Relevance }\end{array}$ & Personalize the learning process. \\
\hline 8 & Goals & Increase the learners' goal-orientedness. \\
\hline 9 & Culture & Familiarize the learners with the target culture. \\
\hline 10 & Group & $\begin{array}{l}\text { Include group work and activities inside and outside of } \\
\text { class. }\end{array}$ \\
\hline 11 & Effort & $\begin{array}{l}\text { Help students realize that it is mainly effort that is needed } \\
\text { for success. }\end{array}$ \\
\hline 12 & $\begin{array}{l}\text { Language } \\
\text { Usefulness }\end{array}$ & Emphasize the usefulness of the language. \\
\hline 13 & Reward & Give the learners other rewards, besides grades. \\
\hline 14 & Finished Product & $\begin{array}{l}\text { Allow students to create products that they can display or } \\
\text { perform. }\end{array}$ \\
\hline 15 & Comparison & Avoid any comparison of students to one another. \\
\hline 16 & Peer-modeling & $\begin{array}{l}\text { Invite experienced students to talk about their positive } \\
\text { learning experiences. }\end{array}$ \\
\hline 17 & Rapport & Develop a good relationship with the students. \\
\hline
\end{tabular}

The mean of each conceptual domain was calculated by finding the mean of the individual micro-strategies that make up the particular conceptual domain. For example, the micro-strategies that make up the conceptual domain Teacher include "teacher prepares properly for the lesson” (student mean = 5.15), "teacher shows a good example by being committed and motivated to helping the students succeed” (student mean = 5.52), "teacher behaves naturally and is genuine in class" (student mean $=5.4$ ), and "teacher is sensitive and accepting as possible" (student mean = 5.2). The means of these 
four micro-strategies in the conceptual domain Teacher were calculated (Teacher student mean $=5.32$. Each conceptual domain was calculated in a like manner, and then rankordered from highest to lowest.

Table 6 presents the rank-ordered data of students' and teachers’ perceptions of the most motivational conceptual domains from most motivational to the least motivational.

Table 6.

Student and Teacher Conceptual Domain Rankings

\begin{tabular}{|r|l|}
\hline $\begin{array}{c}\text { Student } \\
\text { Mean }\end{array}$ & \multicolumn{1}{|c|}{$\begin{array}{c}\text { Student } \\
\text { Perception }\end{array}$} \\
\hline 5.32 & Teacher \\
5.31 & Rapport \\
\hline 5.03 & Climate \\
4.95 & Task \\
4.81 & Self-confidence \\
\hline & Personal \\
\hline 4.69 & relevance \\
& \\
\hline 4.67 & Interest \\
& Language \\
\hline 4.48 & usefulness \\
\hline 4.45 & Autonomy \\
\hline & \\
\hline 4.38 & Effort \\
4.37 & Comparison \\
\hline 4.04 & Goal \\
\hline 3.75 & Group \\
3.71 & Culture \\
\hline 3.22 & Reward \\
\hline 2.73 & Peer-modeling \\
\hline 2.48 & Finished product \\
\hline & \\
\hline
\end{tabular}

\begin{tabular}{|c|c|}
\hline $\begin{array}{c}\text { Teacher } \\
\text { Perception }\end{array}$ & $\begin{array}{c}\text { Teacher } \\
\text { Mean }\end{array}$ \\
\hline Rapport & 5.33 \\
\hline Teacher & 5.31 \\
\hline Comparison & 5.27 \\
\hline Climate & 5 \\
\hline Self-confidence & 4.95 \\
\hline Effort & 4.9 \\
\hline $\begin{array}{l}\text { Language } \\
\text { usefulness }\end{array}$ & 4.7 \\
\hline Autonomy & 4.65 \\
\hline Task & 4.61 \\
\hline Personal relevance & 4.6 \\
\hline Interest & 4.59 \\
\hline Goal & 4.11 \\
\hline Group & 4.11 \\
\hline Reward & 3.8 \\
\hline Culture & 3.72 \\
\hline Finished product & 3 \\
\hline Peer-modeling & 2.83 \\
\hline
\end{tabular}


In order to determine statistical significance between each conceptual domain, two one-way Analysis of Variance (ANOVA) tests by question (conceptual domain) were run, one from the students' responses and one from the teachers' responses.

The results of the first analysis from students' responses revealed a significant effect of question type $(F(16,125)=53.34, p<.0001)$. Post-hoc tests were also run to understand where the precise statistical difference lies in each of the 17 conceptual domains. Lines drawn in table 6 demonstrate the statistical differences among the questions for the students. In other words, each group demarcated by a line is statistically different from the other boxed groupings. For example, the student mean for conceptual domain Teacher is 5.3168, and the mean for the conceptual domain Rapport is ranked slightly lower at 5.3095, but the two categories are not statistically different. Thus, they are grouped together as being equally motivational conceptual domains for students. However, the second statistical grouping of conceptual domains (Climate, Task, and SelfConfidence) is statistically different from the first grouping (Teacher and Rapport). This means students find the individual teaching practices related to Teacher and Rapport more motivating than the teaching practices that make up the conceptual domains Climate, Task and Self-Confidence.

To understand which motivational strategies teachers find most motivating, another one-way ANOVA was run on the data collected from teachers.

The results of the one-way ANOVA for teachers' responses indicate a significant effect by question for teachers $F(16,30)=15.581, p<.0001$. In other words, the rankings of individual questions by teachers also were statistically different from question to question. Table 6 also presents the post-hoc test results for teachers, where 
significant differences between the two groups are demarcated by lines. In particular, the post-hoc results of the teacher survey results show that teachers perceive Rapport, Teacher and Comparison to be the most motivational conceptual domains for students.

A two-way ANOVA group (students and teachers) by question (conceptual domain) was performed to determine if there was a statistically significant difference between 1) students' and teachers' ratings of questions (conceptual domains), 2) combined rankings of questions by students and teachers together. Furthermore, the twoway ANOVA was used to determine if there was a group by question statistical difference. The results of the 2-way ANOVA demonstrated that there was a significant effect of group $F(1,155)=9.128, p=.002$ and by question $F(15,155)=36.42, p<$ .0001 , but there was no group by question interaction $F(1,15)=1.52, p=.089$. Table 7 presents the post-hoc tests run on the question. 
Table 7.

Most Motivational Conceptual Domains According to Students and Teachers

\begin{tabular}{|l|l|l|}
\hline & Conceptual Domain & Group Mean \\
\hline 1 & Teacher & 5.3168 \\
& Rapport & 5.3141 \\
\hline 2 & Climate & 5.0224 \\
\hline 3 & Task & 4.8857 \\
& Self-confidence & 4.8378 \\
\hline 4 & Personal Relevance & 4.6731 \\
& Interest & 4.6512 \\
& Comparison & 4.5449 \\
\hline 5 & Language Usefulness & 4.5226 \\
& Autonomy & 4.4862 \\
& Effort & 4.4839 \\
\hline 6 & Goals & 4.0513 \\
\hline 7 & Group & 3.8168 \\
& Culture & 3.7073 \\
\hline 8 & Reward & 3.3333 \\
\hline 9 & Peer-modeling & 2.7403 \\
& Finished Product & 2.5833 \\
\hline
\end{tabular}

These post-hoc results show where the statistical difference is of the combined student and teacher rankings, which means those conceptual domains that are grouped together are statistically similar and equally as motivating. Student and teacher combined results indicate that Teacher and Rapport are the most motivational conceptual domains.

The results suggest that there is little statistical difference between student and teacher rankings by question and, for the most part, students and teacher perceptions of motivational practices are similar. However, in order to determine which conceptual domains show a statistically significant difference between student and teacher groups, a series of $t$ tests were run on the question with group (teacher vs. student) as the grouping variable and students' responses to each question as the dependent variables. Table 8 presents the results for each $t$ test on the averaged questions. 
Table 8 .

t tests on Averaged Questions Results

\begin{tabular}{|l|l|l|l|}
\hline Question & Conceptual Domain & \multicolumn{1}{|c|}{$F$} & \multicolumn{1}{c|}{$p$} \\
\hline 1 & Teacher & .005 & .942 \\
2 & Climate & .026 & .872 \\
3 & Task & 4.829 & $\mathbf{. 0 2 9}$ \\
4 & Self-confidence & .634 & .427 \\
5 & Interest & 2.07 & .650 \\
6 & Autonomy & 1.12 & .292 \\
7 & Personal Relevance & .122 & .727 \\
8 & Goals & .074 & .786 \\
9 & Culture & .012 & .914 \\
10 & Group & 2.38 & .124 \\
11 & Effort & 3.876 & $\mathbf{. 0 5}$ \\
12 & Language Usefulness & .571 & .451 \\
13 & Reward & 2.498 & .116 \\
14 & Finished Product & 2.34 & .128 \\
15 & Comparison & 7.615 & $\mathbf{. 0 0 6}$ \\
16 & Peer-modeling & .073 & .787 \\
17 & Rapport & .019 & .890 \\
\hline
\end{tabular}

Three different conceptual domains were found to be statistically significant:

Task $(F(1,155)=4.829, p=.029)$, Effort $(F(1,155)=3.876, p=.05)$, and Comparison $(F(1,155)=7.615, p=.006)$. There was no difference between the two groups of any of the other conceptual domains.

Micro-strategy Results

This study contains 49 individual teaching practices, also referred to as microstrategies. In order to determine which of these teaching practices students and teachers find most motivational, both students and teachers rated on a 6-point scale (0-5) how motivational they found each teaching practice. The mean was then calculated and the data were rank-ordered. 
Table 9 presents a complete list of each micro-strategy included in the questionnaires and the mean of each individual micro-strategy. The highest mean indicates the teaching practices that were found to be the most motivational, and the lowest mean indicates the least motivational teaching practice, as perceived by participating students and teachers at Brigham Young University. 
Table 9

Micro-strategy Student and Teacher Results

\begin{tabular}{|c|c|c|c|c|c|}
\hline $\begin{array}{l}\text { Conceptual } \\
\text { Domain }\end{array}$ & Teaching Practice & $\begin{array}{c}\text { Student } \\
\text { Mean }\end{array}$ & SD & $\begin{array}{l}\text { Teacher } \\
\text { Mean }\end{array}$ & SD \\
\hline \multirow[t]{4}{*}{ Teacher } & Properly prepare for the lesson & 5.15 & 0.91 & 5.33 & 0.71 \\
\hline & $\begin{array}{l}\text { Show a good example by being committed and } \\
\text { motivated to helping the students succeed }\end{array}$ & 5.52 & 0.68 & 5.67 & 0.55 \\
\hline & Behave naturally and genuinely in class & 5.4 & 0.81 & 5.17 & 0.79 \\
\hline & Be as sensitive and accepting as possible & 5.2 & 0.88 & 5.07 & 0.87 \\
\hline \multirow[t]{4}{*}{ Climate } & Create a pleasant atmosphere in the classroom & 5.26 & 0.87 & 5.27 & 0.74 \\
\hline & Bring in humor, laughter and smile & 5.37 & 0.97 & 5.43 & 0.68 \\
\hline & Use activities and have fun in class & 5.24 & 1.05 & 5.23 & 0.86 \\
\hline & Have game-like competitions in class & 4.25 & 1.49 & 4.07 & 1.55 \\
\hline \multirow[t]{3}{*}{ Task } & Give clear instructions & 5.22 & 0.85 & 4.9 & 0.8 \\
\hline & Provide guidance about how to do the task & 5.17 & 0.9 & 4.9 & 0.8 \\
\hline & $\begin{array}{l}\text { Clearly state the purpose and the utility of every } \\
\text { task }\end{array}$ & 4.46 & 1.28 & 4.03 & 1.03 \\
\hline Rapport & Develop a good relationship with the students & 5.31 & 0.85 & 5.33 & 0.8 \\
\hline \multirow{5}{*}{$\begin{array}{l}\text { Self- } \\
\text { confidence }\end{array}$} & Give positive feedback and appraisal & 5.17 & 0.88 & 4.9 & 0.88 \\
\hline & $\begin{array}{l}\text { Make sure that students experience success } \\
\text { regularly }\end{array}$ & 4.89 & 1.23 & 4.83 & 1.18 \\
\hline & Encourage students & 5.23 & 0.99 & 5.43 & 0.86 \\
\hline & Teach various learning strategies & 4.13 & 1.54 & 4.43 & 1.19 \\
\hline & $\begin{array}{l}\text { Explain that mistakes are a natural part of } \\
\text { learning }\end{array}$ & 4.64 & 1.11 & 5.13 & 1.29 \\
\hline \multirow[t]{8}{*}{ Interest } & $\begin{array}{l}\text { Select tasks that do not exceed the learners' } \\
\text { competence }\end{array}$ & 4.66 & 1.32 & 4.33 & 1.49 \\
\hline & Select interesting tasks & 4.81 & 1.09 & 4.76 & 0.83 \\
\hline & Choose interesting topics & 4.87 & 1.05 & 4.7 & 0.92 \\
\hline & Offer a variety of materials & 4.58 & 1.1 & 4.73 & 0.83 \\
\hline & Vary the activities & 4.56 & 1.29 & 4.63 & 0.81 \\
\hline & Make tasks challenging to involve the students & 4.7 & 1.09 & 5 & 0.83 \\
\hline & $\begin{array}{l}\text { Build on the learners' interest rather than tests } \\
\text { or grades as the main energizer for learning }\end{array}$ & 4.74 & 1.51 & 4.53 & 1.01 \\
\hline & $\begin{array}{l}\text { Raise learners' curiosity by introducing } \\
\text { unexpected or exotic elements }\end{array}$ & 4.41 & 1.45 & 4.03 & 1.16 \\
\hline \multirow[t]{4}{*}{ Autonomy } & Encourage creative and imaginative ideas & 4.37 & 1.45 & 4.73 & 1.01 \\
\hline & $\begin{array}{l}\text { Encourage questions and other contributions } \\
\text { from the students }\end{array}$ & 5.02 & 1.11 & 5.53 & 0.63 \\
\hline & $\begin{array}{l}\text { Allow students real choices about as many } \\
\text { aspects of learning as possible }\end{array}$ & 3.93 & 1.68 & 4.1 & 1.24 \\
\hline & Act as a facilitator & 4.56 & 1.29 & 4.9 & 1.09 \\
\hline
\end{tabular}




\begin{tabular}{|c|c|c|c|c|c|}
\hline & $\begin{array}{l}\text { Share as much responsibility to organize the } \\
\text { learning process with the students as possible }\end{array}$ & 4.35 & 1.49 & 4 & 1.26 \\
\hline $\begin{array}{l}\text { Personal } \\
\text { relevance }\end{array}$ & $\begin{array}{l}\text { Fill the tasks with personal content that is } \\
\text { relevant to the students }\end{array}$ & 4.69 & 1.31 & 4.6 & 1.13 \\
\hline \multirow[t]{5}{*}{ Goal } & $\begin{array}{l}\text { Help the students develop realistic expectations } \\
\text { about learning }\end{array}$ & 4.57 & 1.24 & 4.77 & 0.9 \\
\hline & $\begin{array}{l}\text { Set up several specific learning goals for the } \\
\text { learners }\end{array}$ & 4.19 & 1.5 & 4.3 & 1.21 \\
\hline & Increase the group’s goal-orientedness & 3.79 & 1.55 & 3.9 & 1.3 \\
\hline & $\begin{array}{l}\text { Tailor instruction to meet the specific language } \\
\text { goals and needs of the students }\end{array}$ & 4.59 & 1.42 & 4.66 & 1.11 \\
\hline & $\begin{array}{l}\text { Help students design their individual study } \\
\text { plans }\end{array}$ & 3.06 & 1.8 & 2.93 & 1.64 \\
\hline \multirow[t]{4}{*}{ Culture } & $\begin{array}{l}\text { Familiarize the learners with the culture of the } \\
\text { language they are learning }\end{array}$ & 5.16 & 1.07 & 5.37 & 0.81 \\
\hline & Use authentic materials & 4.43 & 1.64 & 4.83 & 1.32 \\
\hline & Invite native speakers to class & 3.6 & 1.96 & 3.2 & 1.92 \\
\hline & $\begin{array}{l}\text { Find penpals or "keypals" (Internet } \\
\text { correspondents) for the students }\end{array}$ & 1.64 & 1.34 & 1.5 & 1.07 \\
\hline \multirow[t]{4}{*}{ Group } & Include group work in class & 4.25 & 1.48 & 5.17 & 1.32 \\
\hline & Help students to get to know one another & 4.25 & 1.55 & 5.07 & 0.98 \\
\hline & $\begin{array}{l}\text { Participate as an ordinary member of the group } \\
\text { as much as possible }\end{array}$ & 3.58 & 1.74 & 3.63 & 1.22 \\
\hline & Organize extracurricular activities outside class & 2.92 & 1.72 & 2.57 & 1.76 \\
\hline Effort & $\begin{array}{l}\text { Help students realize that it is mainly effort that } \\
\text { is needed for success }\end{array}$ & 4.38 & 1.37 & 4.9 & 0.84 \\
\hline $\begin{array}{l}\text { Language } \\
\text { usefulness }\end{array}$ & Emphasize the usefulness of the language & 4.48 & 1.49 & 4.7 & 1.15 \\
\hline Reward & Give the learners other rewards besides grades & 3.22 & 1.84 & 3.8 & 1.63 \\
\hline $\begin{array}{l}\text { Finished } \\
\text { product }\end{array}$ & $\begin{array}{l}\text { Allow students to create products that they can } \\
\text { display or perform }\end{array}$ & 2.48 & 1.7 & 3 & 1.46 \\
\hline Comparison & $\begin{array}{l}\text { Avoid any comparison of students to one } \\
\text { another }\end{array}$ & 4.37 & 1.71 & 5.27 & 0.94 \\
\hline $\begin{array}{l}\text { Peer- } \\
\text { modeling }\end{array}$ & $\begin{array}{l}\text { Invite experienced students to talk about their } \\
\text { positive learning experiences }\end{array}$ & 2.73 & 1.87 & 2.83 & 1.88 \\
\hline
\end{tabular}

In order to better understand the data, I have included table 10. This table presents the top ten teaching practices that foreign language students at Brigham Young University find motivational, and the top ten teaching practices that teachers of these foreign language classes perceive to be motivational. The cells that are shaded indicate teaching practices that students and teachers both included in the top ten. 
Table 10

Top 10 Teaching Practices Side-by-side.

\begin{tabular}{|c|c|c|c|}
\hline Top 10 Student Perceptions & $\begin{array}{l}\text { Student } \\
\text { Mean }\end{array}$ & Top 10 Teacher Perceptions & $\begin{array}{l}\text { Teacher } \\
\text { Mean }\end{array}$ \\
\hline $\begin{array}{l}\text { Show a good example by being } \\
\text { committed and motivated to helping } \\
\text { the students succeed }\end{array}$ & 5.52 & $\begin{array}{l}\text { Show a good example by being } \\
\text { committed and motivated to } \\
\text { helping the students succeed }\end{array}$ & 5.67 \\
\hline $\begin{array}{l}\text { Behave naturally and genuinely in } \\
\text { class }\end{array}$ & 5.4 & $\begin{array}{l}\text { Encourage questions and other } \\
\text { contributions from the students }\end{array}$ & 5.53 \\
\hline Bring in humor, laughter and smile & 5.37 & $\begin{array}{l}\text { Bring in humor, laughter and } \\
\text { smile }\end{array}$ & 5.43 \\
\hline $\begin{array}{l}\text { Develop a good relationship with } \\
\text { the students }\end{array}$ & 5.31 & Encourage students & 5.43 \\
\hline $\begin{array}{l}\text { Create a pleasant atmosphere in the } \\
\text { classroom }\end{array}$ & 5.26 & $\begin{array}{l}\text { Familiarize the learners with } \\
\text { the culture of the language they } \\
\text { are learning }\end{array}$ & 5.37 \\
\hline Use activities and have fun in class & 5.24 & Properly prepare for the lesson & 5.33 \\
\hline Encourage students & 5.23 & $\begin{array}{l}\text { Develop a good relationship } \\
\text { with the students }\end{array}$ & 5.33 \\
\hline Give clear instructions & 5.22 & $\begin{array}{l}\text { Create a pleasant atmosphere in } \\
\text { the classroom }\end{array}$ & 5.27 \\
\hline $\begin{array}{l}\text { Be as sensitive and accepting as } \\
\text { possible }\end{array}$ & 5.2 & $\begin{array}{l}\text { Avoid any comparison of } \\
\text { students to one another }\end{array}$ & 5.27 \\
\hline $\begin{array}{l}\text { Provide guidance about how to do } \\
\text { the task }\end{array}$ & 5.17 & $\begin{array}{l}\text { Use activities and have fun in } \\
\text { class }\end{array}$ & 5.23 \\
\hline
\end{tabular}

Multiple tests were run on these individual questions (micro-strategies).

However, these individual micro-strategies were not found to be statistically significant, so no further statistical tests were pursued.

$\underline{\text { Summary }}$

The results of this study reveal that students and teachers generally agree on which teaching practices are most and least motivational. However, findings indicate significant differences between the two groups’ perceptions of the following three conceptual domains: Task, Effort and Comparison. 


\section{Chapter 5}

\section{Conclusion}

In this chapter I return to the key question of how teachers can help motivate language learners in the foreign language classroom. In order to answer this question, I have gathered data from both students and teachers at Brigham Young University. This study has addressed the research questions a) what teaching practices do students find motivational in the foreign language classroom, b) what teaching practices do teachers believe are motivating for students, and c) how these student and teacher perceptions compare. This chapter will present a discussion of the results and implications of the study, the limitations of the study, and suggestions for further research.

\section{Discussion and Implication of Results}

The pressing question of this study is how do student and teacher perceptions of motivational strategies compare? This question will be answered in two ways. First, how the students and teachers perceptions were similar, and second how the students and teachers perceptions were different. This chapter will also note how the student and teacher responses of the current study compared with the results of the teacher responses from Csizer and Dörnyei’s (1998) study.

The results indicate that, with a few exceptions, students and teachers agree as to how motivational they find various teaching practices. There was very little statistical difference between the rankings of the students and those of the teachers. This suggests that students and teachers believe that concentrating on the same types of teaching practices will increase students' motivation to learn. Since the two groups were so similar in their responses, the results of the post-hoc test run on the two-way ANOVA 
between student and teacher groups suggest the most motivational conceptual domains to the least motivational, as perceived by students and teachers. Table 11 presents this list of the most motivational conceptual domains to the least motivational. While one conceptual domain may have a higher mean, it is only statistically different than another group if it is separated by a box. The conceptual domains Teacher and Rapport were ranked by both groups as the most motivational. Based on the results of this study, both teachers and students believe that the teacher's dedication to the class and the subject matter, as well as the teacher's willingness to develop a good relationship with the students as the best way for teachers to increase students’ motivation.

Table 11.

Most Motivational Conceptual Domains According to Students and Teachers

\begin{tabular}{|c|l|c|}
\hline & \multicolumn{1}{|c|}{ Conceptual Domain } & $\begin{array}{c}\text { Group } \\
\text { Mean }\end{array}$ \\
\hline 1 & Teacher & 5.3168 \\
& Rapport & 5.3141 \\
\hline 2 & Climate & 5.0224 \\
\hline 3 & Task & 4.8857 \\
& Self-confidence & 4.8378 \\
\hline 4 & Personal Relevance & 4.6731 \\
& Interest & 4.6512 \\
& Comparison & 4.5449 \\
\hline 5 & Language Usefulness & 4.5226 \\
& Autonomy & 4.4862 \\
& Effort & 4.4839 \\
\hline 6 & Goals & 4.0513 \\
\hline 7 & Group & 3.8168 \\
& Culture & 3.7073 \\
\hline 8 & Reward & 3.3333 \\
\hline 9 & Peer-modeling & 2.7403 \\
& Finished Product & 2.5833 \\
\hline
\end{tabular}


Table 12 presents a list of the individual teaching practices that make up each conceptual domain broken up into the 9 different statistically significant groups. The first group includes the most motivational teaching practices and the last group includes the least motivational teaching practices. 
Table 12.

Most Motivational Teaching Practices to Least Motivational Teaching Practices

\begin{tabular}{|c|c|c|}
\hline 1 & $\begin{array}{l}\text { Teacher } \\
\text { Rapport }\end{array}$ & $\begin{array}{l}\text { Properly prepare for the lesson } \\
\text { Show a good example by being committed and motivated to } \\
\text { helping the students succeed } \\
\text { Behave naturally and genuinely in class } \\
\text { Be as sensitive and accepting as possible } \\
\text { Develop a good relationship with the students }\end{array}$ \\
\hline 2 & Climate & $\begin{array}{l}\text { Create a pleasant atmosphere in the classroom } \\
\text { Bring in humor, laughter and smile } \\
\text { Use activities and have fun in class } \\
\text { Have game-like competitions in class }\end{array}$ \\
\hline 3 & $\begin{array}{l}\text { Task } \\
\text { Self-confidence }\end{array}$ & $\begin{array}{l}\text { Give clear instructions } \\
\text { Provide guidance about how to do the task } \\
\text { Clearly state the purpose and utility of every task } \\
\text { Give positive feedback and appraisal } \\
\text { Make sure that students experience success regularly } \\
\text { Encourage students } \\
\text { Teach various learning strategies } \\
\text { Explain that mistakes are a natural part of learning }\end{array}$ \\
\hline 4 & $\begin{array}{l}\text { Personal Relevance } \\
\text { Interest } \\
\text { Comparison }\end{array}$ & $\begin{array}{l}\text { Fill the tasks with personal content that is relevant to the } \\
\text { students } \\
\text { Select tasks that do not exceed the learners' competence } \\
\text { Select interesting tasks } \\
\text { Choose interesting topics } \\
\text { Offer a variety of materials } \\
\text { Vary the activities } \\
\text { Make tasks challenging to involve the students } \\
\text { Build on the learners' interest rather than tests or grades as } \\
\text { the main energizer for learning } \\
\text { Raise learners' curiosity by introducing unexpected or exotic } \\
\text { elements } \\
\text { Avoid any comparison of students to one another }\end{array}$ \\
\hline 5 & $\begin{array}{l}\text { Language Usefulness } \\
\text { Autonomy } \\
\text { Effort }\end{array}$ & $\begin{array}{l}\text { Emphasize the usefulness of the language } \\
\text { Encourage creative and imaginative ideas } \\
\text { Encourage questions and other contributions from the } \\
\text { students } \\
\text { Allow students real choices about as many aspects of } \\
\text { learning as possible } \\
\text { Act as a facilitator } \\
\text { Share as much responsibility to organize the learning process } \\
\text { with the students as possible } \\
\text { Help students realize that it is mainly effort that is needed for } \\
\text { success }\end{array}$ \\
\hline
\end{tabular}




\begin{tabular}{|l|l|l|}
\hline 6 & Goals & $\begin{array}{l}\text { Help the students develop realistic expectations about } \\
\text { learning } \\
\text { Set up several specific learning goals for the learners } \\
\text { Increase the group's goal-orientedness } \\
\text { Tailor instruction to meet the specific language goals and } \\
\text { needs of the students } \\
\text { Help students design their individual study plans }\end{array}$ \\
\hline 7 & $\begin{array}{l}\text { Group } \\
\text { Culture }\end{array}$ & $\begin{array}{l}\text { Familiarize the learners with the culture of the language they } \\
\text { are learning } \\
\text { Use authentic materials } \\
\text { Invite native speakers to class } \\
\text { Find penpals or "keypals" (Internet correspondents) for the } \\
\text { students } \\
\text { Include group work in class } \\
\text { Help students to get to know one another } \\
\text { Participate as an ordinary member of the group as much as } \\
\text { possible } \\
\text { Organize extracurricular activities outside class }\end{array}$ \\
\hline 8 & Reward & $\begin{array}{l}\text { Give the learners other rewards besides grades } \\
\text { Allow students to create products that they can display or } \\
\text { perform } \\
\text { Invite experienced students to talk about their positive } \\
\text { Finished Product }\end{array}$ \\
\hline
\end{tabular}

The findings of this study differ from those of Csizer and Dörnyei (1998) in several ways. Csizer and Dörnyei asked the same questions of English teachers in Hungary and asked them to rate the frequency and importance of each teaching practice. Based on the responses they gathered, Csizer and Dörnyei also came up with a rankordered list of the most motivational conceptual domains, which they call the Ten Commandments for motivating language learners. Table 13 presents the results of Csizer and Dörnyei’s (1998) study, which differ from the results of this study. 
Table 13.

Ten Commandments for Motivating Language Learners

\begin{tabular}{|l|l|l|}
\hline Rank & CD & Description \\
\hline 1 & Teacher & Set a personal example with your own behavior. \\
\hline 2 & Climate & $\begin{array}{l}\text { Create a pleasant, relaxed atmosphere in the } \\
\text { classroom. }\end{array}$ \\
\hline 3 & Task & Present the tasks properly. \\
\hline 4 & Rapport & Develop a good relationship with the learners. \\
\hline 5 & Self-confidence & Increase the learners' linguistic self-confidence. \\
\hline 6 & Interest & Make the language classes interesting. \\
\hline 7 & Autonomy & Promote learner autonomy. \\
\hline 8 & $\begin{array}{l}\text { Personal } \\
\text { Relevance }\end{array}$ & Personalize the learning process. \\
\hline 9 & Goal & Increase the learners' goal-orientedness. \\
\hline 10 & Culture & Familiarize learners with the target culture. \\
\hline 18 & Comparison & Avoid comparing students one to another. \\
\hline
\end{tabular}

It is difficult to compare the results of this study and the results of Csizer and Dörnyei, as Csizer and Dörnyei did not calculate the statistical significance of differences between conceptual domain groups. Their study simply presents the rank-ordered mean from highest to lowest based on Hungarian teacher' perceptions. Table 14 shows a side by side comparison of the results of this study versus the results of Csizer and Dörnyei’s (1998) study. 
Table 14.

Comparison of Csizer and Dörnyei with Ruesch

\begin{tabular}{|c|c|c|c|}
\hline Rank & $\begin{array}{l}\text { Csizer and } \\
\text { Dörnyei CD }\end{array}$ & Rank & Ruesch CD \\
\hline 1 & Teacher & 1 & $\begin{array}{l}\text { Teacher } \\
\text { Rapport }\end{array}$ \\
\hline 2 & Climate & 2 & Climate \\
\hline 3 & Task & 3 & $\begin{array}{l}\text { Task } \\
\text { Self-confidence }\end{array}$ \\
\hline 4 & Rapport & 4 & $\begin{array}{l}\text { Personal Relevance } \\
\text { Interest } \\
\text { Comparison }\end{array}$ \\
\hline 5 & Self-confidence & 5 & $\begin{array}{l}\text { Language Usefulness } \\
\text { Autonomy } \\
\text { Effort }\end{array}$ \\
\hline 6 & Interest & 6 & Goals \\
\hline 7 & Autonomy & 7 & $\begin{array}{l}\text { Group } \\
\text { Culture }\end{array}$ \\
\hline 8 & $\begin{array}{l}\text { Personal } \\
\text { Relevance }\end{array}$ & 8 & Reward \\
\hline 9 & Goal & 9 & $\begin{array}{l}\text { Peer-modeling } \\
\text { Finished Product }\end{array}$ \\
\hline 10 & Culture & & \\
\hline
\end{tabular}

The most interesting comparison between these studies is the difference between the ranking of Rapport. For students and teachers in this study Rapport ranked equally with Teacher as the most motivational conceptual domain. In Csizer and Dörnyei’s (1998) study, Rapport ranked only as the fourth most motivating conceptual domain. Perhaps there are cultural differences between American and Hungarian teachers with regards to Rapport.

This difference in the two studies' findings is important, because it supports the value of gathering data from both students and teachers from the same language learning environment. If students' perceptions are left out of the equation, then teachers might be 
missing what really motivates students to achieve in the foreign language classroom. In this study, the importance that students and teachers from Brigham Young University both placed on teachers establishing rapport with their students as a way to motivate students was much higher than the importance Hungarian teachers assigned to this particular conceptual domain.

Another part of answering the research question "How do student and teacher perceptions compare?” is to look, not only at the similarities, but also at the differences between students' and teachers' perceptions. The results show that, for the most part, students and teachers rankings were statistically similar. This is why running a post-hoc test on the two-way ANOVA to come up with a list of what teachers should do in the classroom to increase motivation is appropriate. This test provides a rank-ordered list of the most motivational teaching practices to least from both students' and teachers’ perspectives. In addition, $t$ tests were also run between student and teacher groups. The $t$ tests revealed that although 14 of the conceptual domains were statistically the same between groups, 3 were statistically different. Table 15 presents a list of the conceptual domains that were statistically different.

Table 15.

Conceptual Domains that are Statistically Different Between Groups

\begin{tabular}{|l|l|l|}
\hline Conceptual Domain & $F$ & $P$ \\
\hline Task & 4.829 & .029 \\
Effort & 3.876 & .05 \\
Comparison & 7.615 & .006 \\
\hline
\end{tabular}

The first conceptual domain that is statistically different between student and teacher groups is Task. Students ranked Task higher than teachers as the fourth highest 
domain, whereas teachers ranked Task as the ninth highest. Students place significantly ( $p=.029)$ higher importance on teaching practices related to Task than teachers do. Thus results indicate that instructors might give more attention to Task in the classroom. Teaching practices related to Task include giving clear instructions, providing guidance about how to do the task, and clearly stating the purpose and utility of every task. Effort is another conceptual domain with a statistically significant difference between student and teacher groups. While students ranked Task significantly higher than teachers, teachers ranked Effort statistically higher $(p=.05)$ than students. Teachers ranked Effort as the sixth highest mean, and students ranked Effort as the tenth highest mean. This suggests that teachers believe "helping students realize that it is mainly effort that is needed for success" to be a significantly more motivational teaching practice than students do.

The last conceptual domain that has a statistically significant difference between student and teacher groups is Comparison. Comparison is the most statistically different of each of the three statistically different conceptual domains ( $p=.006)$. Teachers ranked Comparison as the third highest mean, and the post-hoc results on the one-way ANOVA by teacher results show that there is no statistical difference in the ranking of Comparison by teachers from Teacher and Rapport. This means that teachers perceive teaching practices related to Comparison as being equally as motivational as teaching practices related to Teacher and Rapport. Students, on the other, hand ranked Comparison as the eleventh highest mean, just under Effort.

Teachers at Brigham Young University believe that avoiding comparisons from one student to another is particularly important for student motivation, whereas students 
did not rank that teaching practice as being particularly motivating. This result may indicate that teachers avoid such comparisons, so that students may not notice Comparison as being motivating or not motivating. Perhaps if teachers were to compare their students in the classroom and students noticed, the results of this study would be slightly different on this question.

Another interesting point about the conceptual domain Comparison is the difference in ranking between American teachers' perceptions from this study and Hungarian teachers’ perception from Csizer and Dörnyei’s (1998) study. Teachers at BYU ranked Comparison as one of the three most motivational conceptual domains, whereas Hungarian teachers ranked Comparison in last place as the least motivational conceptual domain. Results suggest a possible cultural difference in the way American and Hungarian teachers perceive and use inter-student comparisons in the classroom. Limitations of the Study

There were four main limitations of the current study. The first is that the study was conducted at one university. Gathering data from multiple universities would provide a larger sample size in order to get more data to answer the research question. The small number $(\mathrm{N}=156)$ of respondents represents another potential limitation of the study. Had more students responded, the population of foreign language students at Brigham Young University would have been better represented. Moreover, few teachers responded to the survey, especially in comparison to the numbers of student respondents. It is difficult to predict how the results might have differed if teachers had been better represented. The final limitation of the study is that data were collected from students and teachers from multiple languages and different language levels. It is possible that 
students learning one language would be motivated by something different than students learning another language or learning at a different language level.

In spite of the limitations, there were still enough student and teacher responses in order to allow for valid statistical analysis. Furthermore, this study provides an important step in comparing both student and teacher perceptions of motivational teaching practices.

Suggestions for Future Research

The findings of the study suggest areas for future research. Researchers should give particular attention to questions of Task, Effort and Comparison. Qualitative studies, in particular, may provide greater insights into why students find teaching practices related to Task so much more motivating than do teachers.

Additionally, a study could be conducted to find out the reason why teachers find strategies related to Effort and Comparison more motivational than students. It would also to be interesting to gather data from teachers to find out if not comparing students one to another is really part of building rapport with the students

Based on the difference in ranking between this study and the Csizer and Dörnyei (1998) study on the conceptual domain Comparison, it would also be interesting to find out why teachers from each country ranked that same conceptual domain so differently. Ethnographic methods or discourse analysis may yield important information about the role inter-student comparisons play (or do not play) in various cultures.

Additionally, future studies should gather data from students and teachers at more than one university. The data could be compared to see if there is a difference in the perceptions of students from one university to the next. If there were no difference, then 
having data from more students and more teachers would give a larger sample size resulting in a more accurate representation of student and teacher perceptions.

Finally, scholars should compare the results of different language groups. It would be interesting to know if a student learning Arabic finds different teaching practices motivational than a student learning Russian or Chinese. If there are differences between students studying different languages, then teachers of particular language learning groups would know which teaching practices to emphasize in their classrooms. If, on the other hand, future studies reveal no differences, then the results could support the current study and really show teachers what teaching practices they can concentrate on in order to increase student motivation.

\section{Conclusion}

The results of the present study help foreign language teachers understand a few vital things. First, the results show that teachers' perceptions of what motivates students are strikingly similar to what actually does motivate students in the classroom. Both students and teachers believe that when the teacher prepares properly, develops a relationship with the students, creates a comfortable and relaxing environment for learning and encourages students, students are more motivated to learn.

The results, when compared with previous studies, also show the importance of gathering data from both students and teachers. If researchers want to know how teachers can motivate students, it is important to gather data from everyone participating in the classroom environment—both students and teachers. The differences between this study and the Csizer and Dörnyei (1998) study illustrate this, as well as the significant differences between students’ and teachers’ perceptions on Task, Effort and Comparison. 
The results of this study related to Task, Effort, and Comparison also help teachers understand the few places where teachers and students do not agree. For example, findings suggest that teachers should place more emphasis on strategies related to Task such as: presenting learning activities clearly, explaining why the learning activities are important, and helping students understand directions. Students are more motivated when they know why they are engaging in the tasks the teacher assigns and how the task is contributing to the overall learning goals and objectives. Also, if teachers are concerned about fostering student motivation, according to the results, they do not need to emphasize the importance of student effort as much as developing a relationship with the students and setting an example with their own positive behavior. Not comparing students was not found to be particularly motivating for students, though teachers perceived it to be. Perhaps students did not rank Comparison as being a particularly motivating conceptual domain, because teachers place such great importance on not comparing students that it just does not happen in the classroom, or perhaps teachers view not comparing students as part of building rapport with the students.

By eliciting opinions from both students and teachers in the same language learning environment, the present study sheds more light on how teachers can help increase student motivation. Specifically, teachers should focus on: preparing properly for the lesson, showing a good example by being committed and motivated to helping the student succeed, behaving naturally and genuinely in class, being sensitive and accepting as possible, developing a good relationship with the students, creating a pleasant atmosphere in the classroom, bringing in humor, using activities and having fun in class, including game-like competitions in class, giving clear instructions, providing guidance 
about how to do the task, clearly stating the purpose of each task, giving positive feedback and appraisal, making sure that students experience success regularly, encouraging students, teaching various learning strategies and explaining that mistakes are a natural part of learning.

The results of the study indicate that the best way for teachers to increase student motivation include focus on teaching practices related to the conceptual domains Teacher, Rapport, and Climate. Some new suggestions for how to motivate foreign language learners in the foreign language classroom include: setting a positive example (Teacher), building a solid rapport with students (Rapport), creating a pleasant, relaxed atmosphere in the classroom (Climate), making sure the students understand the tasks (Task), and increasing the learners' linguistic self-confidence (Self-Confidence). As teachers concentrate on teaching practices related to these conceptual domains, students will feel more motivated in the foreign language classroom. 


\section{References}

Cheng, H., \& Dörnyei, Z. (2007). The use of motivational strategies in language instruction: The case of EFL teaching in Taiwan. Innovation in Language Learning and Teaching, 1, 153-174.

Crookes, G., \& Schmidt, R. W. (1991). Motivation: Reopening the research agenda. Language Learning: A Journal of Applied Linguistics, 41, 469-512.

Csizer, K., \& Dörnyei, Z. (2005). The internal structure of language learning motivation and its relationship with language choice and learning effort. The Modern Language Journal, 89, 19-36.

Dörnyei, Z. (1990, April). Analysis of motivation components in foreign language learning. Paper presented at the World Congress of Applied Linguistics, sponsored by the International Association of Applied Linguistics, $9^{\text {th }}$, Thessaloniki, Greece. (ERIC Document Reproduction Service No. ED 323810)

Dörnyei, Z. (1994). Motivation and motivating in the foreign language classroom. The Modern Language Journal, 78, 273-284.

Dörnyei, Z. (2000). Teaching and researching motivation. New York; Longman.

Dörnyei, Z. (2001). New themes and approaches in second language motivation research. Annual Review of Applied Linguistics, 21, 43-59.

Dörnyei, Z. (2001a). Motivational strategies and the language classroom. Cambridge: Cambridge University Press.

Dörnyei, Z., \& Csizer, K. (1998). Ten commandments for motivating language learners: Results of an empirical study. Language Teaching Research,2, 203-225. 
Ely, C. M. (1986). Language learning motivation: A descriptive and causal analysis. The Modern Language Journal, 70, 28-35.

Gardner, R. C., Masgoret, A. M., Tennant, J., \& Mihic, L. (2004). Integrative motivation: Changes during a year-long intermediate-level language course. Language Learning, 54, 1-34.

Gardner, R. C. (1985). Social psychology and second language learning the role of attitudes and motivation. London: E. Arnold.

Green, C. F. (1999). Categorising motivational drives in second language acquisition. Language, Culture, and Curriculum, 12, 265-279.

Norton, B. (2001). Non-participation, imagined communities and the language classroom. In M. P. Breen (Ed.), Learner contributions to language learning (pp. 159-171). Harlow, UK: Longman.

Oxford, R. L. (2003). Language learning styles and strategies: Concepts and relationships. International Review of Applied Linguistics in Language Learning, $41,271-278$.

Oxford, R., \& Shearin, J. (1994). Language learning motivation: Expanding the theoretical framework. The Modern Language Journal, 78, 12-28.

Price, J., \& Gascoigne, C. (2006). Current perceptions and beliefs among incoming college students towards foreign language study and language requirements. Foreign Language Annals, 39, 383.

Roberts, L. P. (1992). Attitudes of entering university freshmen toward foreign language study: A descriptive analysis. The Modern Language Journal, 76, 275-283. 
Ryan, S. (2006). Language learning motivation within the context of globalisation: An L2 self within an imagined global community. Critical Inquiry in Language Studies, 3, 23-45.

Shoaib, A., \& Dörnyei. Z. (2005). Affect in life-long learning: Exploring L2 motivation as a dynamic process. In P. Benson \& D. Nunan (Eds.), Learners’ stories: Difference and diversity in language learning (pp. 22-41). Cambridge: Cambridge University Press.

Tremblay, P. F., \& Gardner, R. C. (1995). Expanding the motivation construct in language learning. The Modern Language Journal, 79, 505-518.

Ushioda, E. (2006). Language motivation in a reconfigured Europe: Access, identity, autonomy. Journal of Multilingual and Multicultural Development, 2006, 27, 148161. 


\section{Appendix A}

Informed Consent

This research survey is being conducted by Ashley Ruesch, a graduate student in the Language Teaching and Acquisition program, to determine which teaching practices students and teachers find motivational and how they compare. The survey should take approximately 10 minutes to answer.

By completing this online survey, you agree to participate in this study. Your responses are anonymous and no identifying information will be collected. You must be at least 18 years old to participate. If you are not 18 or older, please do not complete the survey.

If you have questions regarding this study you may contact Ashley Ruesch at (801) 5926663; email, ashley.ruesch@gmail.com.

If you have questions regarding your rights as a participant in research projects, you may contact Christopher Dromey, Ph.D, Chair of the Institutional Review Board for Human Subjects, 133 TLRB, Brigham Young University, Provo, UT 84602; phone, (801) 4226461; email, christopher_dromey@byu.edu. 
Appendix B

Student Survey Questions

Age:

Gender:

Language:

Current foreign language class (Russian 101, Russian 102, etc.):

Following is a list of various teaching practices that are sometimes used by foreign language teachers. For each item, please indicate how big a role that particular practice plays in motivating you to learn the language. Choose one number only.

$0=$ My teacher does not use this practice.

$1=$ This practice has no effect on my motivation.

2 = This practice plays only a minor role in motivating me.

$3=$ This practice plays somewhat of a role in motivating me.

4 = This practice plays a considerable role in motivating me.

5 = This practice plays a major role in motivating me.

Practices used by teachers

Circle one number only

The teacher properly prepares for the lesson.

012345

The teacher shows a good example by being committed and motivated to helping the students succeed.

012345

The teacher tries to behave naturally and is genuine in class.

012345 
The teacher is sensitive and accepting as they can be.

012345

The teacher creates a pleasant atmosphere in the classroom.

012345

The teacher brings in humor, laughter and smiles.

012345

The teacher uses activities and has fun in class.

012345

The teacher has game-like competitions in class.

012345

The teacher gives clear instructions.

012345

The teacher provides guidance about how to do the task.

012345

The teacher clearly states the purpose and the utility of every task.

012345

The teacher develops a good relationship with the students.

012345

The teacher gives positive feedback and appraisal.

012345

The teacher makes sure that students experience success regularly.

012345

The teacher encourages students.

012345

The teacher explains that mistakes are a natural part of learning.

012345

The teacher selects tasks that do not exceed the learners' competence. $\quad 012345$

The teacher selects interesting tasks.

012345

The teacher chooses interesting topics.

012345

The teacher offers a variety of materials.

012345

The teacher varies the activities.

012345

The teacher makes tasks challenging to involve the students.

012345

The teacher builds on the learners' interest rather than tests or grades as the main energizer for learning.

The teacher raises learners' curiosity by introducing unexpected or exotic elements. 
The teacher encourages creative and imaginative ideas.

012345

The teacher encourages questions and other contributions from the students. 012345

The teacher shares as much responsibility to organize the learning process with the

students as possible.

012345

The teacher fills the tasks with personal content that is relevant to the students.

012345

The teacher helps the students develop realistic expectations about learning.0 12345

The teacher sets up several specific learning goals for the learners.

012345

The teacher increases the group's goal-orientedness.

012345

The teacher tailors instruction to meet the specific language goals and needs of the students.

The teacher helps students design their individual study plans.

012345

The teacher familiarizes the learners with the culture of the language they are learning.

The teacher uses authentic materials (i.e printed or recorded materials that were produced for native speakers rather than students).

012345

The teacher invites native speakers to class.

012345

The teacher finds penpals or "keypals” (Internet correspondents) for the students.

The teacher includes group work in class.

012345

The teacher helps students to get to know one another.

012345

The teacher participates as an ordinary member of the group as much as possible. 
The teacher organizes extracurricular activities outside class.

The teacher helps students realize that it is mainly effort that is needed for success.

012345

The teacher emphasizes the usefulness of the language.

012345

The teacher gives the learners other rewards besides grades.

012345

The teacher allows students to create products that they can display or perform.

012345

The teacher avoids any comparison of students to one another.

012345

The teacher invites experienced students to talk about their positive learning experiences.

012345

The teacher teaches various learning strategies.

012345

The teacher allows me real choices about as many aspects of learning as possible.

012345

The teacher acts as a facilitator.

012345 


\section{Appendix C}

Teacher Survey Questions

Age:

Gender:

Language:

Course Levels Taught:

Following is a list of various teaching practices that are sometimes used by foreign language teachers. For each item, please indicate how big a role that particular practice plays in motivating your students to learn the language. Use the following answer key. Choose one number only.

$$
\begin{aligned}
& 0=\text { I do not use this practice } . \\
& 1=\text { This practice has no effect on my students' motivation. } \\
& 2=\text { This practice plays only a minor role in motivating my students. } \\
& 3=\text { This practice plays somewhat of a role in motivating my students. } \\
& 4=\text { This practice plays a considerable role in motivating my students. } \\
& 5=\text { This practice plays a major role in motivating my students. }
\end{aligned}
$$

\section{Practices used by teachers}

Circle one number

only

I properly prepare for the lesson.

I show a good example by being committed and motivated to helping the students succeed.

I try to behave naturally and am genuine in class. 
I create a pleasant atmosphere in the classroom.

012345

I bring in humor, laughter and smile.

I use activities and have fun in class.

012345

I have game-like competitions in class.

012345

I give clear instructions.

012345

I provide guidance about how to do the task.

012345

I clearly state the purpose and the utility of every task.

012345

I develop a good relationship with the students.

012345

I give positive feedback and appraisal.

012345

I make sure that students experience success regularly.

012345

I encourage students.

012345

I explain that mistakes are a natural part of learning.

012345

I select tasks that do not exceed the learners' competence.

012345

I select interesting tasks.

I choose interesting topics.

012345

I offer a variety of materials.

012345

I vary the activities.

012345

I make tasks challenging to involve the students.

012345

I build on the learners' interest rather than tests or grades as the main energizer for learning.

012345

I raise learners’ curiosity by introducing unexpected or exotic elements.

012345

I encourage creative and imaginative ideas.

012345 
I encourage questions and other contributions from the students.

012345

I share as much responsibility to organize the learning process with the students as

possible.

012345

I fill the tasks with personal content that is relevant to the students. $\quad 0012345$

I help the students develop realistic expectations about learning.

012345

I set up several specific learning goals for the learners.

012345

I increase the group’s goal-orientedness.

012345

I tailor instruction to meet the specific language goals and needs of the students.

012345

I help students design their individual study plans.

012345

I familiarize the learners with the culture of the language they are learning. 012345

I use authentic materials (i.e printed or recorded materials that were produced for native speakers rather than students).

012345

I invite native speakers to class.

012345

I find penpals or "keypals” (Internet correspondents) for the students.

012345

I include group work in class.

012345

I help students to get to know one another.

012345

I participate as an ordinary member of the group as much as possible. $\quad 012345$

I organize extracurricular activities outside class.

012345

I help students realize that it is mainly effort that is needed for success. $\quad 012345$

I emphasize the usefulness of the language.

012345

I give the learners other rewards besides grades.

012345

I allow students to create products that they can display or perform.

012345 
I avoid any comparison of students to one another.

012345

I invite experienced students to talk about their positive learning experiences.

012345

I teach various learning strategies.

012345

I allow students real choices about as many aspects of learning as possible. 012345

I act as a facilitator.

012345 
Appendix D

Student Survey Micro-Strategy Results Rank-ordered

\begin{tabular}{|c|c|}
\hline Teaching Practice & $\mathrm{X}$ \\
\hline $\begin{array}{l}\text { Show a good example by being committed and motivated to helping the students } \\
\text { succeed }\end{array}$ & 5.52 \\
\hline Behave naturally and am genuine in class & 5.4 \\
\hline Bring in humor, laughter and smile & 5.37 \\
\hline Develop a good relationship with the students & 5.31 \\
\hline Create a pleasant atmosphere in the classroom & 5.26 \\
\hline Use activities and have fun in class & 5.24 \\
\hline Encourage students & 5.23 \\
\hline Give clear instructions & 5.22 \\
\hline Sensitive and accepting as possible & 5.2 \\
\hline Provide guidance about how to do the task & 5.17 \\
\hline Give positive feedback and appraisal & 5.17 \\
\hline Familiarize the learners with the culture of the language they are learning & 5.16 \\
\hline Properly prepare for the lesson & 5.15 \\
\hline Encourage questions and other contributions from the students & 5.02 \\
\hline Make sure that students experience success regularly & 4.89 \\
\hline Choose interesting topics & 4.87 \\
\hline Select interesting tasks & 4.81 \\
\hline $\begin{array}{l}\text { Build on the learners' interest rather than tests or grades as the main energizer for } \\
\text { learning }\end{array}$ & 4.74 \\
\hline Make tasks challenging to involve the students & 4.7 \\
\hline Fill the tasks with personal content that is relevant to the students & 4.69 \\
\hline Select tasks that do not exceed the learners' competence & 4.66 \\
\hline Explain that mistakes are a natural part of learning & 4.64 \\
\hline Tailor instruction to meet the specific language goals and needs of the students & 4.59 \\
\hline Offer a variety of materials & 4.58 \\
\hline Help the students develop realistic expectations about learning & 4.57 \\
\hline Vary the activities & 4.56 \\
\hline Act as a facilitator & 4.56 \\
\hline Emphasize the usefulness of the language & 4.48 \\
\hline Clearly state the purpose and the utility of every task & 4.46 \\
\hline Use authentic materials & 4.43 \\
\hline Raise learners' curiosity by introducing unexpected or exotic elements & 4.41 \\
\hline Help students realize that it is mainly effort that is needed for success & 4.38 \\
\hline Encourage creative and imaginative ideas & 4.37 \\
\hline Avoid any comparison of students to one another & 4.37 \\
\hline $\begin{array}{l}\text { Share as much responsibility to organize the learning process with the students } \\
\text { possible }\end{array}$ & 4.35 \\
\hline
\end{tabular}


Have game-like competitions in class

Include group work in class

Help students to get to know one another

Set up several specific learning goals for the learners

Teach various learning strategies

Allow students real choices about as many aspects of learning as possible

Increase the group's goal-orientedness

Invite native speakers to class

Participate as an ordinary member of the group as much as possible

Give the learners other rewards besides grades

Help students design their individual study plans

Organize extracurricular activities outside class

Invite experienced students to talk about their positive learning experiences

Allow students to create products that they can display or perform

Find penpals or "keypals" (Internet correspondents) for the students 
Appendix E

Teacher Survey Micro-Strategy Results Rank-ordered

\begin{tabular}{|c|c|}
\hline Teaching Practice & Mean \\
\hline $\begin{array}{l}\text { Show a good example by being committed and motivated to helping the students } \\
\text { succeed }\end{array}$ & 5.67 \\
\hline Encourage questions and other contributions from the students & 5.53 \\
\hline Bring in humor, laughter and smile & 5.43 \\
\hline Encourage students & 5.43 \\
\hline Familiarize the learners with the culture of the language they are learning & 5.37 \\
\hline Properly prepare for the lesson & 5.33 \\
\hline Develop a good relationship with the students & 5.33 \\
\hline Create a pleasant atmosphere in the classroom & 5.27 \\
\hline Avoid any comparison of students to one another & 5.27 \\
\hline Use activities and have fun in class & 5.23 \\
\hline Behave naturally and am genuine in class & 5.17 \\
\hline Include group work in class & 5.17 \\
\hline Explain that mistakes are a natural part of learning & 5.13 \\
\hline Sensitive and accepting as possible & 5.07 \\
\hline Help students to get to know one another & 5.07 \\
\hline Make tasks challenging to involve the students & 5 \\
\hline Give clear instructions & 4.9 \\
\hline Provide guidance about how to do the task & 4.9 \\
\hline Give positive feedback and appraisal & 4.9 \\
\hline Act as a facilitator & 4.9 \\
\hline Help students realize that it is mainly effort that is needed for success & 4.9 \\
\hline Make sure that students experience success regularly & 4.83 \\
\hline Use authentic materials & 4.83 \\
\hline Help the students develop realistic expectations about learning & 4.77 \\
\hline Select interesting tasks & 4.76 \\
\hline Offer a variety of materials & 4.73 \\
\hline Encourage creative and imaginative ideas & 4.73 \\
\hline Choose interesting topics & 4.7 \\
\hline Emphasize the usefulness of the language & 4.7 \\
\hline Tailor instruction to meet the specific language goals and needs of the students & 4.66 \\
\hline Vary the activities & 4.63 \\
\hline Fill the tasks with personal content that is relevant to the students & 4.6 \\
\hline $\begin{array}{l}\text { Build on the learners' interest rather than tests or grades as the main energizer for } \\
\text { learning }\end{array}$ & 4.53 \\
\hline Teach various learning strategies & 4.43 \\
\hline Select tasks that do not exceed the learners' competence & 4.33 \\
\hline
\end{tabular}


Set up several specific learning goals for the learners

Allow students real choices about as many aspects of learning as possible

Have game-like competitions in class

Clearly state the purpose and the utility of every task

Raise learners' curiosity by introducing unexpected or exotic elements

Share as much responsibility to organize the learning process with the students as

possible

Increase the group's goal-orientedness

4.03

Give the learners other rewards besides grades

Participate as an ordinary member of the group as much as possible

Invite native speakers to class

Allow students to create products that they can display or perform

Help students design their individual study plans

Invite experienced students to talk about their positive learning experiences

Organize extracurricular activities outside class

Find penpals or "keypals” (Internet correspondents) for the students 